\title{
NEW REMARKS ON THE LITHOLOGY AND BIOSTRATIGRAPHY OF THE CRETACEOUS DEPOSITS FROM ISTRIA DEPRESSION (BLACK SEA SHELF)
}

\author{
LARISA TERTIȘ, IOAN I. BUCUR, EMANOIL SĂ SĂ RAN \& \\ LUCREȚIA GHERGARI ${ }^{1}$
}

\begin{abstract}
The lithological and micropaleontological study of samples collected from several boreholes drilled in the Mesozoic deposits of Istria Depression (Black See shelf) allowed the characterization of intersected Cretaceous successions.

The Berriasian - Valanginian deposits are terrigenous, represented mainly by sandstones in the lower parts, and clays above. It is impossible to document the presence of Hauterivian-Aptian deposits in the succession. The Albian deposits are still terrigenous (predominantly clays, sometimes with sponge spicules). The Cenomanian transgressive deposits are coarser, and contain Conicorbitolina conica (d'Archiac), Rotalipora cushmani (Morrow) and Hedbergella-Praeglobotruncana sp. The following Turonian?-Campanian-Maastrictian deposits are micritic limestones with planctonic foraminifera in specific successions: Globotruncana cf. elevata (Brotzen), Globotruncana bulloides (Vogler), Globotruncana arca (Cushman), Globotruncana contusa (Cushman), Gansserina sp. For these specific successions the assemblage indicates a Campanian-Maastrictian age. The age of the most underlying deposits could be estimated only by comparisons with published data (Bă ncilă et al., 1997).
\end{abstract}

KEYWORDS: Black Sea shelf, Cretaceous, lithology, biostratigraphy.

\section{INTRODUCTION}

Black Sea has represented an area of economic and scientific interest since the first data on the bore hole samples from the Romanian offshore. Since then hundreds of boreholes were drilled by Romanian and foreign companies, leading to a huge amount of geological data. The major geological units of the adjacent areas (North-Dobrogea Orogen, Babadag Basin and Moesic Platform) preserve their specific features also in the Romanian shelf area of the Black Sea (fig.1).

This study focused on core samples collected from reference and productive boreholes located on the northern sector of Istria Depression. This structural unit was defined as the depressionary area located between the northern and central branches of the Euxinic threshold (Pă trut et. al. 1974). This threshold was interpreted as a well-defined continental paleoslope working since the Upper Eocene, but which probably limited the extension of the shelf deposits already starting with the Upper Cretaceous.

\footnotetext{
1 "Babeş-Bolyai" University, Department of Geology. Str. Kogălniceanu 1, 3400 Cluj-Napoca, Romania
} 


\section{LITHOLOGICAL REMARKS}

The studied samples were collected from three distinctive structures located on the northern (Egreta structure), northwestern (Lebă da West structure) and eastern (Unirea structure) borders of the Istria Depression.

The synthetic petrographical data are presented below:

1. The deposits from Egreta structure are mainly siliciclastic, represented in the lower and middle part by fine to coarse well-sorted sandstones, interlayered by siltic claystones/mudstones (PI. I., fig. 2). Within the coarse deposits, normal grading is noticeable, while within the fine ones ripples and convolute lamination is currently present. The bioclasts occur only in the middle and upper part of the succession, represented by fragments of echinoderms, molluscs, and uni-

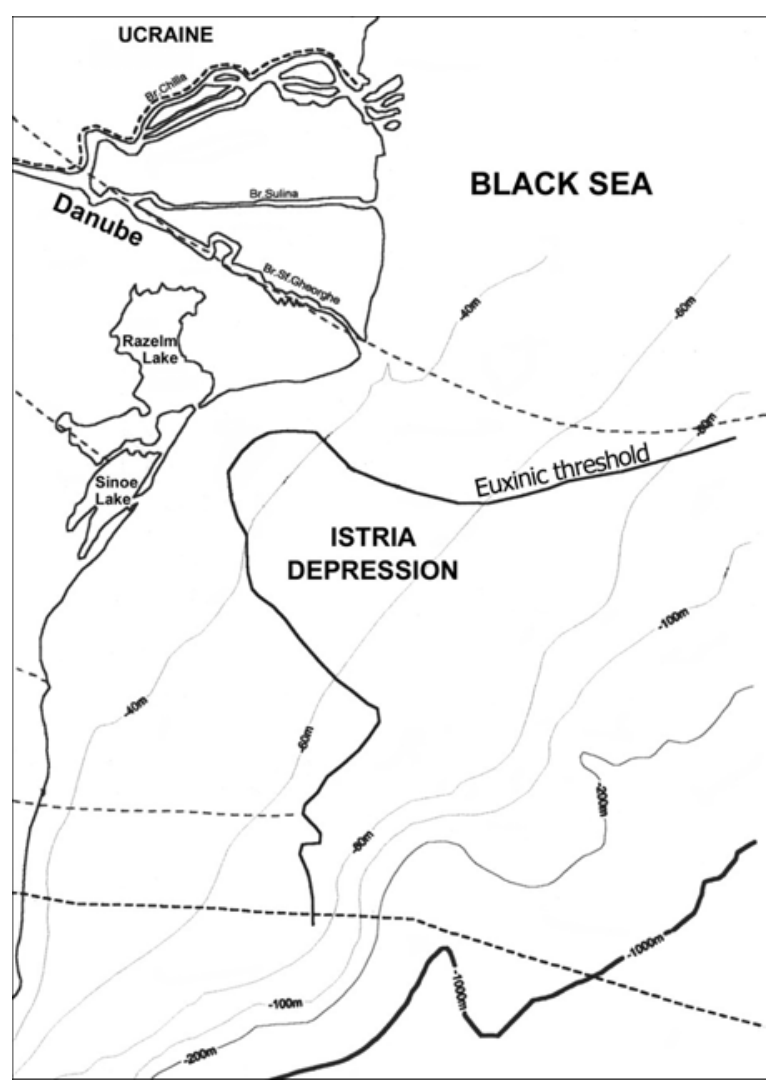

Fig. 1 - Black Sea shelf dentified red algae.

The deposits from the upper part of the succession consist of coarse sandstones and microconglomerates with fragments of brachiopods, molluscs, echinoderms and forams (PI. I, fig. 1,3,5). The Cenomanian age of these deposits at the top of the succession was established based on Conicorbitolina conica (D'ARCHIAC). Along the whole succession the autigenic minerals are represented by glauconite.

2. A relatively small number of samples from Lebă da West structure were studied, and they represent a short interval of about 50 meters. Lithologically, terrigenous limestones with reworked bioclasts (fragments of echinoderms, molluscs, red algae, forams) associated with siliciclastites (quartzite lithoclasts and quartz clasts) and autigenic minerals (phosphates and glauconite) were identified (PI. I, fig. 4,6). In some samples the siliciclasts dominate, leading to the local development of bioclastic sandstones. These deposits are interlayered with fine bioclastic deposits mainly consisting of sponge spicules embedded into a claystone/mudstone matrix (PI. II, fig.2). The Cenomanian age of these 
deposits is documented by Paraphylum amphiroaeforme LEMOINE.

3. The deposits from Unirea structure are dominated by siltic claystones/ mudstones (PI. II, fig. 2) sometimes interlayered with fine sandstones (PI. II, fig. 4, 6 ). The fine layers are intensely bioturbated and contain sponge spicules, planctonic forams (Globotruncanidae), echinoderm fragments and silt-sized terrigenous components (PI. II, fig. 1, 5). Phosphates and glauconite are commonly associated with these deposits. The Late Cretaceous age was established on the basis of planctonic forams species.

Interpretation: The fine-grained sediments with both biogenic and terrigenous components are hemipelagic deposits (Stow et al., 1996), associated with turbidite deposits. Phosphates are commonly associated with hemipelagites deposited in oxygen-deficient settings, while glauconites occur in more shallow-water hemipelagites (Stow et al., 1996).

\section{THE MICROFOSSIL ASSEMBLAGES AND THEIR BIOSTRATIGRAPHICAL SIGNIFICANCE}

Orbitolina (Conicorbitolina) conica (D'ARCHIAC), Rotalipora cushmani (MORROW) and Hedbergella-Praeglobotruncana sp. that were identified in Egreta structure are index species for the Cenomanian, the Late Cenomanian respectively (Schroeder \& Neumann, 1985, ; Robaszinski et al., 1984).

The globotruncanidae association that is present in the deposits from Unirea structure including Globotruncanita sp. cf. Globotruncanita elevata (BROTZEN), Globotruncana bulloides (VOGLER), Globotruncana arca (CUSHMAN), Contusotruncana contusa (CUSHMAN), Globotruncana sp., Globotruncanella sp. Gansserina sp. cf. Gansserina wiedenmayeri (GANDOLFI) and Gansserina sp. was previously described from Campanian-Maastrichtian deposits (Robaszinski et al., 1984). It established the stratigraphical limits of the studied successions. The successions lacking these species can be dated only in comparison with previous information (Bă ncilă et al., 1997).

\section{CONCLUSIONS}

The lithological-petrographical and micropaleontological study of the samples collected from several boreholes drilled in Istria Depression (Black Sea plateau) lead to a brief characterization of some Cretaceous successions.

The Upper Jurassic deposits are mainly limestones based on the reworked fragments that were found in the Lower Cretaceous turbidites. They were overlaid by siliciclastic deposits during Berriasian-Valanginian, that are mainly sandstone-rich (proximal turbidites) in the lower part and clay-rich (distal turbidites) in the upper part. The Hauterivian-Aptian interval can be hardly documented based on the studied samples. The Albian deposits are dominated by hemipelagites, sometimes interlayered with pelagites containing sponge spicules. The transgressive feature of the Cenomanian deposits is given by the coarse sediments that formed during this stage. They are followed by ?TuronianCampanian-Maastrichtian micritic limestones, often clay-rich, containing planctonic forams. 
Only the Cenomanian and the Late Cretaceous samples provided index micropaleontological assemblages that were used for documenting the age of the hosting deposit.

Acknowledgements. L. Tertis thanks the geological team from PETROMAR for the acces to the samples and some unpublished data.

\section{REFERENCES}

BĂNCILĂ I., NEAGU T., MUȚIU R. \& DRAGASTAN O. (1997) - Jurassic-Cretaceous stratigraphy and tectonic framework of the Romanian Black Sea offshore. Revue Roumaine de Géologie, 41, p.65-76, București.

PĂTRUȚ et al. (1975) - Cercetă ri asupra structurii geologice a Platformei Continentale a Mă rii Negre și poziț ia primelor foraje de cercetare geologică , Raport Intern.

ROBASZINSKI F., CARON M., GONZALES DONOSO J.M. \& WONDERS A.A.H. (eds.) (1984) - Atlas of late Cretaceous Globotruncanids. Revue de Micropaléontologie, 26/34, p.145-305.

SCHROEDER R. \& NEUMANN M. (eds.) (1985) - Les grands foraminiféres du Crétacé moyen de la région méditerranéenne. Geobios. Mém spec. 7, 161p., 68 pl., Lyon.

STOW, D. A. V., READING, H. G., COLLINSON, J. D. (1996) - Deep seas. In: Reading H. G, (ed), .Sedimentary environments: processes, facies and stratigraphy. Third ed., Blackwell Science, p. 395-453.

\section{PLATES}

Plate I

Fig.1, 3, 5 - Coarse sandstones and microconglomerates with fragments of brachiopods, molluscs, echinoderms and forams. 1- sample IV-1-FLV; 3-sample 14E-CM5-E1; 5-sample 822-LW-CM5.

Fig. 2 - Siltic claystones/mudstones. Sample 35U-CM10-E3.

Fig. 4 - Terrigenous limestones with reworked bioclasts. Sample 14E-CM7-E5.

Fig. 6 - Siliciclastites (quartzite lithoclasts and quartz clasts) and autigenic minerals (phosphates and glauconite).Sample 14E-CM-E1.

Scale-bar $=0,6 \mathrm{~mm}$.

\section{Plate II}

Fig. 1, 5 - fine layers with sponge spicules, planctonic forams (Globotruncanidae), and siltsized terrigenous components. 1-sample 35U-CM5; 5-sample 822-LW-CM2.

Fig. 2 - Siltic claystones/mudstones. Sample 14E-CM9-E4.

Fig. 3 - Sponge spicules embedded into a claystone/mudstone matrix. Sample 35U-CM7. Fig. 4, 6 - Sandy claystones/mudstones. Sample 60P-CM2 $(6=\mathrm{N}+)$.

Scale-bar $=0,6 \mathrm{~mm}(1,3,5)$ and $1,1 \mathrm{~mm}(2,4,6)$. 
CRETACEOUS DEPOSITS FROM ISTRIA DEPRESSION (BLACK SEA SHELF)

\section{Plate III}

Fig. 1 - Conicorbitolina conica (D'ARCHIAC). Sample 14E-CM5-E1, x 35.

Fig. 2 - Rotalipora cushmani (MORROW). Sample CM15, x 70.

Fig. 3 - Hedbergella?-Praeglobotruncana? sp. Sample CM15, x 70.

Fig. 4-6 - Globotruncana bulloides VOGLER, x 70.

4-sample 35U-CM5; 5-sample 35U-CM7; 6-sample 35U-CM6.

Fig. 7 - Globotruncana sp. Sample 35U-CM5, x 70.

Fig. 8 - Globotruncana cf. elevata (BROTZEN). Sample 63P-CM5, x 70.

Fig. 9-12 - Globotruncana arca (CUSHMAN), x 70.

9-sample 35U-CM5; 10, 11-sample 63P-CM5; 12-sample 60P-CM5.

\section{Plate IV}

Fig. 1, 2 - Ganserina cf. wiedenmayeri (GANDOLFI), x 70.

1-sample 60P-CM5; 2-sample 35U-CM5.

Fig. 3 - Ganserina sp. Sample 63P-CM5, x 70.

Fig. 4 - Globotruncana contusa (CUSHMAN). Sample CM9, x 70.

Fig. 5-8 - Globotruncanidae indet., $x 70$.

5-sample 60P-CM5; 8, 9, 10-sample CM8.

Fig. 9 - Hedbergella sp. Sample 63-CM5, x 70.

Fig. 10, 11 - Heterohelix sp., x 70.

10-sample 35U-CM6; 11-sample 60P-CM5. 
PLATE I
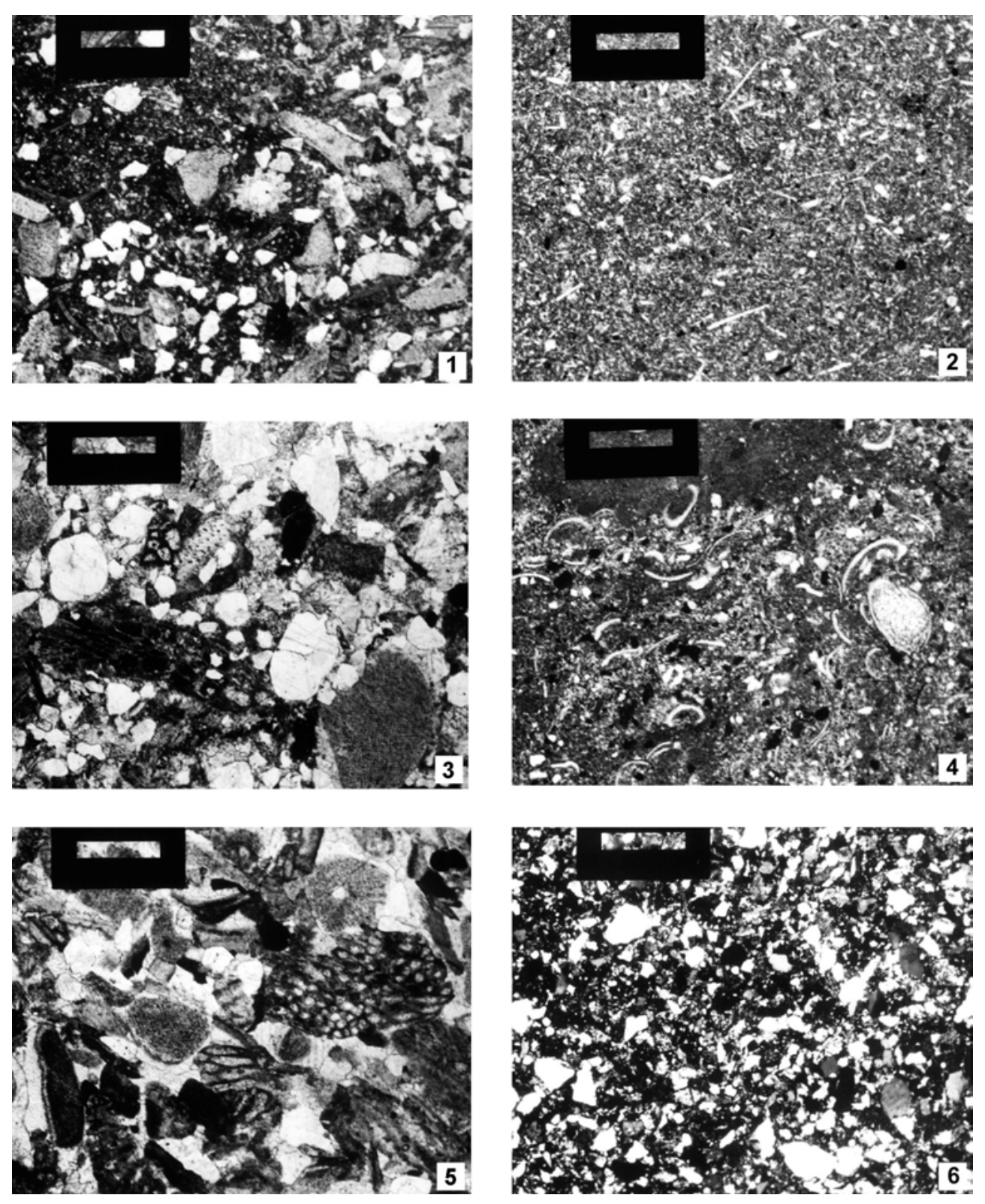
PLATE II
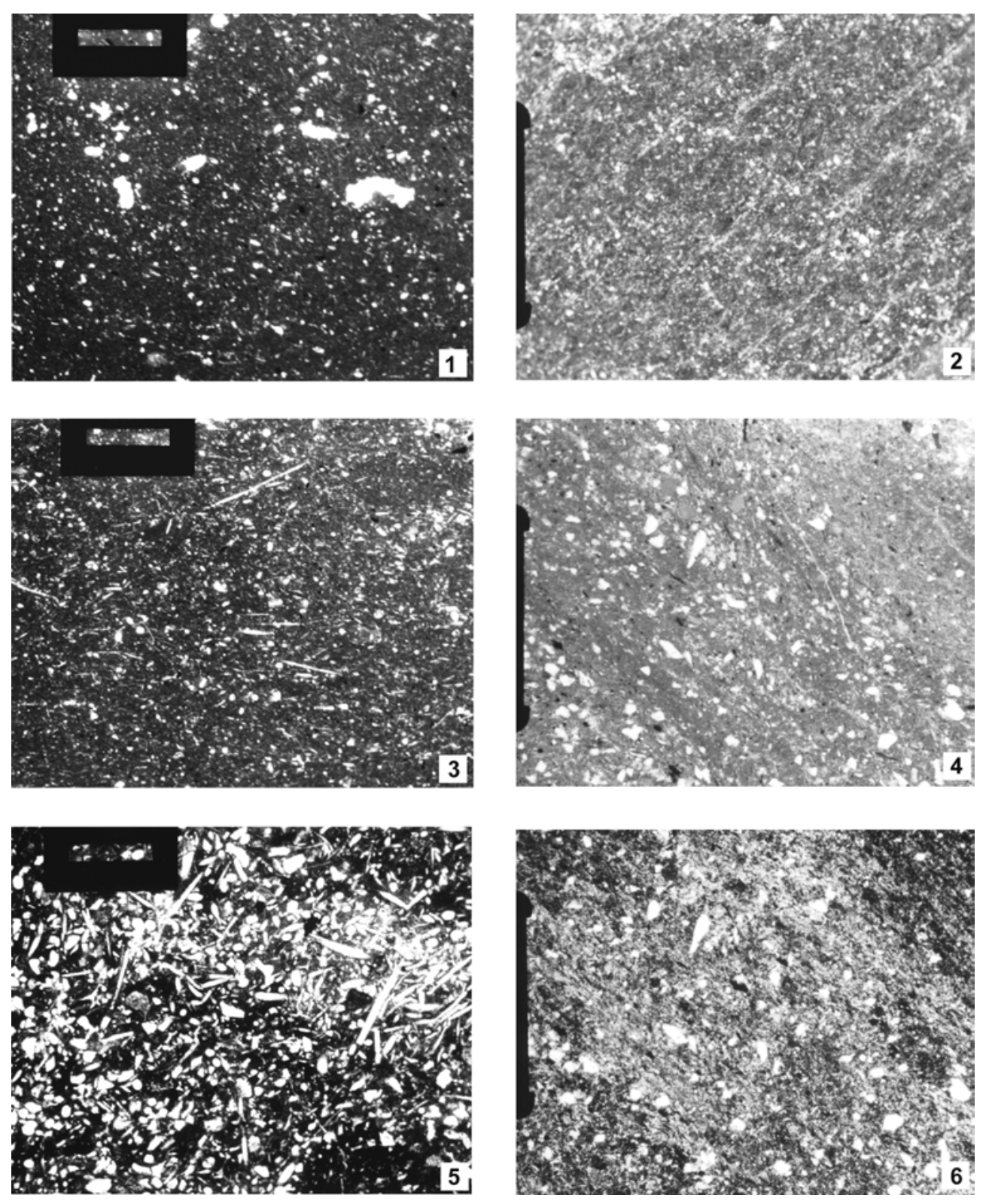
PLATE III
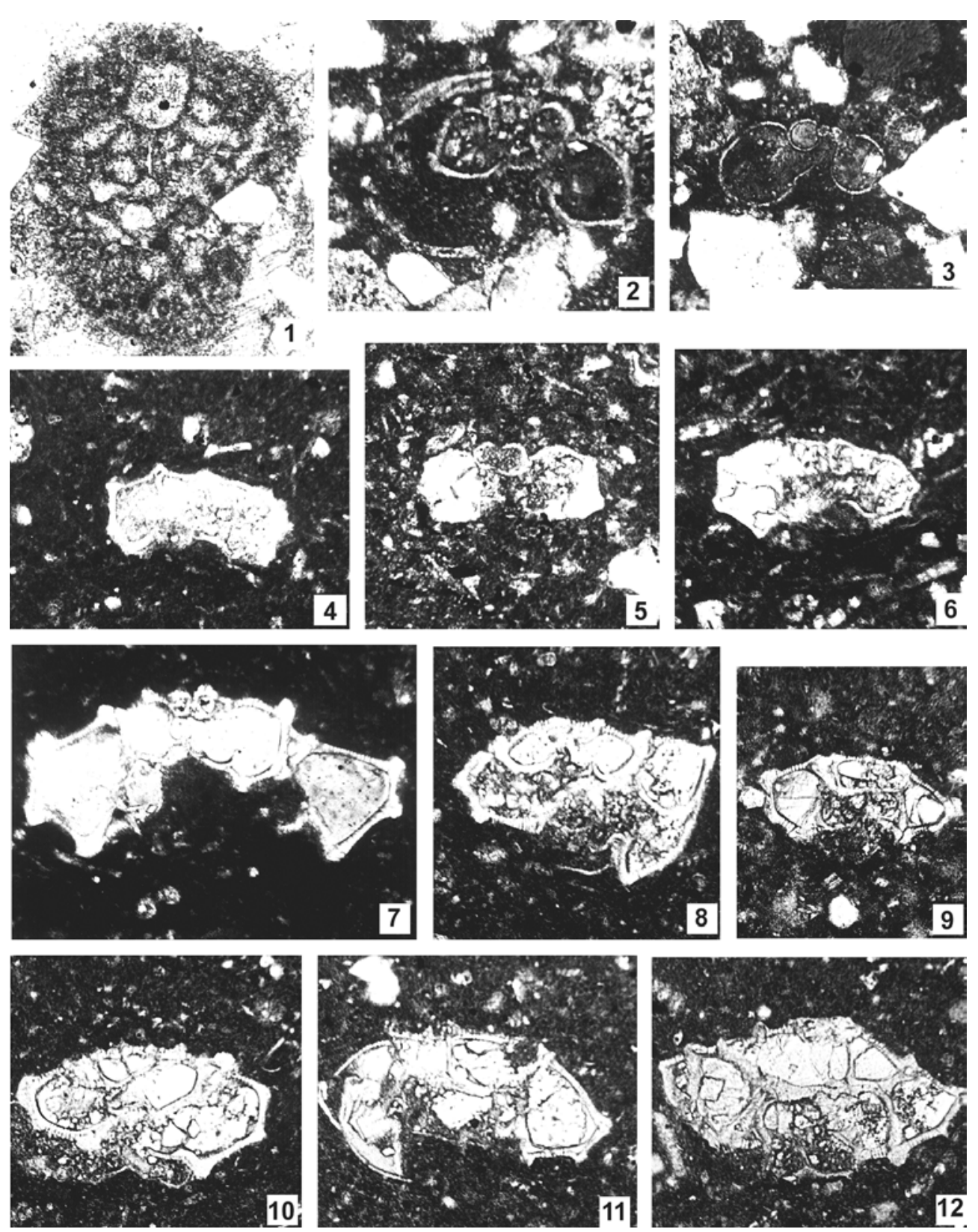
PLATE IV
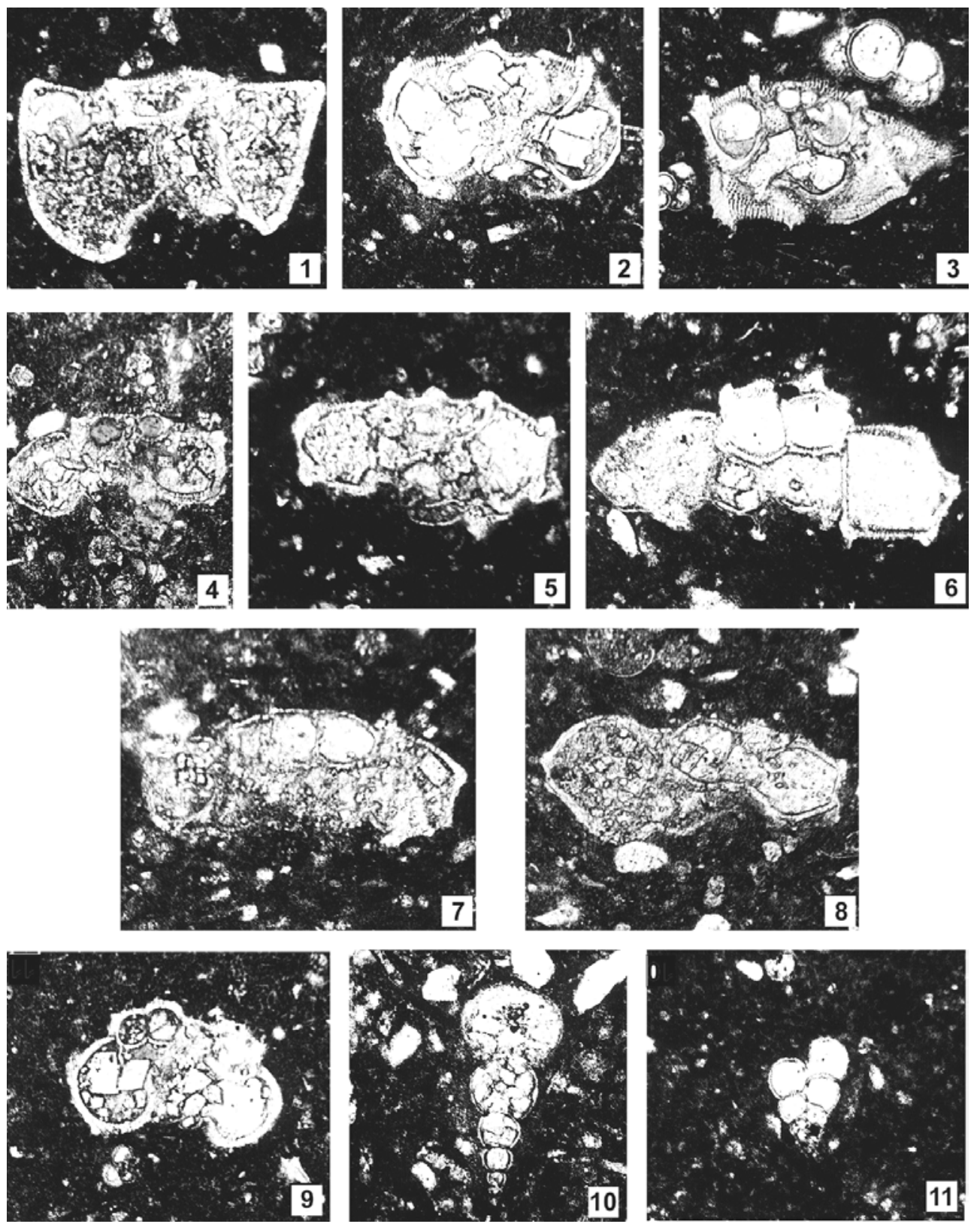